D. J. WALlaCe,* K. R. CAMPOS,*C. S. SChULTZ,*A. KLAPARS, D. ZEWGE, B. R. CRUMP,

\title{
Synthesis of Taranabant
}

Key words

\section{taranabant}

asymmetric hydrogenation

amidation

palladium

rhodium

\section{1. $t$-BuONa (1.04 equiv) 2. $\mathrm{Ts}_{2} \mathrm{O}\left(1.04\right.$ equiv), $-20^{\circ} \mathrm{C}$ $85 \%(2.62 \mathrm{~mol}$ scale $)$}

A<smiles>CC([O-])=C(Cc1ccc(Cl)cc1)c1cccc(C#N)c1</smiles>

B
$\mathrm{Pd}_{2}(\mathrm{dba})_{3}(2.3 \mathrm{~mol} \%)$ $\mathrm{dppb}(6.9 \mathrm{~mol} \%)$<smiles>CC(C)(Oc1ccc(C(F)(F)F)cn1)C(N)=O</smiles>

c

$$
\frac{\begin{array}{c}
\mathrm{H}_{2} \mathrm{O}_{2}(1.7 \text { equiv }) \\
\mathrm{K}_{2} \mathrm{CO}_{3}(0.8 \text { equiv })
\end{array}}{\text { DMSO, r.t. }}
$$

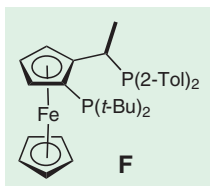

cyanuric chloride i-PrOAc-DMF, r.t. $90 \%$ ( 0.9 mol scale)<smiles>C/C(NC(=O)C(C)(C)Oc1ccc(C(F)(F)F)cn1)=C(/Cc1ccc(Cl)cc1)c1cccc(C#N)c1</smiles>
$\mathrm{NBD}_{2} \mathrm{Rh}(\mathrm{F})(0.05 \mathrm{~mol} \%)$ $\mathrm{CF}_{3} \mathrm{CH}_{2} \mathrm{OH}, 40^{\circ} \mathrm{C}$<smiles>CC(NC(=O)C(C)(C)Oc1ccc(C(F)(F)F)cn1)C(Cc1ccc(Cl)cc1)c1cccc(C(N)=O)c1</smiles><smiles>CC(NC(=O)C(C)(C)Oc1ccc(C(F)(F)F)cn1)C(Cc1ccc(Cl)cc1)c1cccc(C#N)c1</smiles>

Significance: Taranabant is a potential selective inverse agonist of the cannabinoid-1 receptor which is implicated in the regulation of feeding behaviour. Hence, taranabant is being developed for the treatment of obesity. The synthesis depicted incorporates three key features: (1) a simple highly stereoselective synthesis of the vinyl tosylate $(\mathbf{A} \rightarrow$ B); (2) an efficient synthesis of a tetrasubstituted enamide by palladium-catalyzed amidation (B $\rightarrow$ D); and (3) a highly efficient asymmetric hydrogenation to create two adjacent stereogenic centers in a single step $(\mathbf{E} \rightarrow \mathbf{G})$.
Comment: An earlier synthesis based on dynamic kinetic resolution (C.-y. Chen et al. Org. Process

Res. Dev. 2007, 11, 616) required the use of sodium azide to introduce the nitrogen atom and suffered from lack of any suitable solid intermediates. In the present synthesis, the direct asymmetric hydrogenation of enamide $\mathbf{D}$ to taranabant was precluded because the nitrile in $\mathbf{D}$ coordinated preferentially to the rhodium catalyst. Therefore a two-step detour (nitrile hydrolysis, $\mathbf{D} \rightarrow \mathbf{E}$ ) and amide dehydration of $\mathbf{G}$ was required. 